\title{
Surprisingly diversified macrofauna in mobile gravels and pebbles from high-energy hydrodynamic environment of the 'Raz Blanchard' (English Channel)
}

\author{
Foveau Aurélie ${ }^{1, *}$, Dauvin Jean-Claude ${ }^{1}$
}

\author{
${ }^{1}$ Normandie Univ., UNICAEN, UNIROUEN, Laboratoire Morphodynamique Continentale et Côtière, \\ UMR CNRS 6143 M2C, 24, rue des Tilleuls, F-14000 Caen, France \\ * Corresponding author : Aurélie Foveau, email address : aurelie.foveau@ifremer.fr
}

\begin{abstract}
:
Our study concerns the sampling of patches of mobile gravel and pebbles at 14 stations (25 to $66 \mathrm{~m}$ water depth) in an area of hard bottom located in the 'Raz Blanchard' (between Cap de La Hague in France and Alderney in the Channel Islands, UK). The samples collected from these benthic habitats with scattered fauna were sieved on 1-mm mesh and subjected to meticulous sorting, revealing the presence of a highly diversified mobile fauna. The epifauna and vagile macrofauna $(>1 \mathrm{~mm})$ account for 140 taxa (120 species, 17 genera and three other levels of identification). Amphipods and polychaetes dominate the taxonomic richness, while crustaceans represent $75 \%$ of the fauna. Among these taxa, two species are new for the English Channel marine fauna. Biological Traits Analysis (BTA) indicates that the species show adaptation to such strong hydrodynamic conditions, owing to their small size which allows them to live in interstitial environments and on biological substrates, and which can locally modify the hydrodynamic conditions.
\end{abstract}

\section{Highlights}

- The Raz Blanchard is an area of high-energy hydrodynamics with a hard and irregular seabed. The fauna in these particular benthic habitats is highly diversified. The fauna is dominated by crustaceans and polychaetes. The fauna is small-sized and interstitial. Two species are new for the English Channel.

Keywords : Amphipods, Polychaetes, Taxonomic richness, Hard bottom, High-energy environments 
The English Channel is characterized by the presence of strong tidal currents which in some places exceed $3 \mathrm{~m} / \mathrm{s}$. The sedimentation of fine particles is impossible in such areas with strong hydrodynamics, and the sea bed is covered by pebbles and blocks, and sometimes outcrops of bedrock (Larsonneur et al., 1982). This is the case off the northern coast of Cotentin and south of the Isle of Wight, where there are projects for the installation of tidal stream turbines (SEEDA, 2007; Thiébot et al., 2015). Nevertheless, several authors (see Cabioch, 1968; Retière, 1979; Brown et al., 2002, 2004a, b; Diesing et al., 2009; Coggan and Diesing 2011, 2012) have described the presence of patches of mobile sediment on hardbottoms in high-energy environments in the western and central parts of the English Channel. In these rocky areas, it is not feasible to sample benthic fauna with grabs since the mobile coarse sediment covers very small patches. Therefore, sampling is only possible with equipment such as the Rallier du Baty dredge, which can be used when sediment patches are encountered (mainly gravels and pebbles) (Cabioch, 1968; Retière, 1979).

In such coarse sediments, the grains are smooth, clean and lack any fixed fauna, reflecting the important role of bed load transport in such high-energy environments, which are very well oxygenated to a depth of several decimetres beneath the seabed. These sediments are described as very poor in fauna, in particular when sieving is carried out with a 2 mm mesh (Cabioch, 1968; Retière, 1979).

The French Public Body ADEME (Agence de l'Environnement et de la Maîtrise de l'Energie) supports various Research and Development ("R\&D") projects in the domain of renewable energy, including tidal turbines. In this context, the research project Pile \& Tide was financed by the ADEME and our laboratory was placed in charge of investigating the benthic habitats in the Raz Blanchard area (seabed composition and benthic communities).

Describing or measuring the functioning of ecosystems is difficult. As it encompasses many phenomena (Hooper et al., 2005), the overall functioning of an ecosystem is complex and involves many factors relating to the chemical, physical and biological components of the 
system. The use of multiple variables offers an appropriate approach to describe the functioning of entire ecosystems (Duffy and Stachowicz, 2006). Biological Traits Analysis (BTA) is a tool developed for this purpose, which takes into account the biological characteristics of benthic species (life-history, morphological and behavioural aspects) to analyse the functioning of benthic communities (Verissimo et al., 2012). BTA has been applied to marine ecosystems (see for example Bremner et al., 2006) or in freshwater environments (see Menezes et al., 2010). Even if BTA requires further improvement, previous research can provide information on the general relationships between traits, species and their environment. This method appears to be useful in two domains: (1) assessing the effects of human activities and subsequent management strategies and (2) making predictions about future changes (Bremner, 2008).

The main objectives of this paper are 1) to describe the main characteristics of the representative fauna collected in such high-energy hydrodynamic environments and 2) to present the main biological traits of life of fauna adapted to coarse mobile sediment habitats.

\section{Materials and methods}

\subsection{Study site}

The Raz Blanchard is located in the western part of the English Channel to the North of the Normand-Breton Gulf, occupying an area with the strongest tidal currents in Europe. It is situated in a strait between the north-western tip of the Cotentin (Cap de La Hague, France) and the island of Alderney (UK). At its northern limit, the Raz Blanchard is between 2 and 5 nautical miles wide, being situated on a line joining the lighthouses of Mannez on Alderney and La Hague on the Cotentin. To the south, it is delimited by a line between the Schôle bank and the Cap de Flamanville, to the west by a line between Mannez lighthouse and the Schôle bank and to the east by a line between the Cap de Flamanville and the 'Basse-Bréfort' buoy (Fig. 1). The water depth is comprised between 25 and $66 \mathrm{~m}$.

The sea bed is complex, made up of a substratum composed of granite and calcareous rocks of Cambrian, Silurian and Cretaceous age (Boillot, 1964; Hommeril, 1967). The surficial sediments, where they exist, are composed of gravel and pebbles (Hommeril, 1967; Larsonneur et al., 1982). 
A total of 38 stations were visited during three sampling campaigns: (1) 28-29 April 2015; (2) 19-23 October 2015 and (3) 1-2 April 2016 (Fig. 1). Dredges were towed along the bottom for 5 minutes (except in cases where the gear was hauled off the bottom for security reasons). Out these stations, 20 dredges were unsuccessful and only 14 yielded a sufficient volume of sediment for the purposes of study. In the remaining four cases, the sample was of insufficient size to be studied. The sampling depth is comprised between 25 to $66 \mathrm{~m}$. Nevertheless, the volume of sediment sampled at the 14 successful stations varied from $0.5 \mathrm{~L}$ to $32 \mathrm{~L}$. For marine sediments sampled with the Rallier du Baty dredge, Cabioch (1968) and Retière (1979) estimated that a minimum sediment volume of $30 \mathrm{~L}$ is required to obtain a representative sample of the species and benthic communities in the English Channel. Only three sampling stations yielded a sediment volume $\geq 30$ L (Table 2), with one sample having a volume of $15 \mathrm{~L}$ and the 10 others having small volumes between 0.5 and 2 L. Fig. 2 illustrates the types of sampled sediment; i.e. gravels and pebbles with or without sessile epifauna. The number of empty dredges and the low volume of sediment collected highlight the difficulties of sampling on such types of seabed. Samples were sieved through a 1-mm circular mesh and preserved in formalin solution and then in $70 \%$ ethanol after the sorting step. In this particular area (where few (if any) benthic samples have been collected), we sieved our samples through 1-mm circular mesh in the laboratory. For coarser sediments collected in the English Channel, it is common practice to sieve through 2-mm circular mesh on board the oceanographic vessel (see Foveau, 2009 and Lozach, 2011 for examples). In the present study, to ensure an adequate definition of this poorly known benthic community, we favoured the use of a 1-mm sieve.

Species determination was carried out in the laboratory using a binocular microscope and relevant literature (see collection of the Synopsis of the British Fauna, for example). In the present study, mainly the vagile epifauna and infauna are taken into account. However, due to the high relevance of some fixed species (number of collected individuals, natural heritage value or engineer species), we added three species to the analysis (Musculus discors, 
Due to the small number of successful dredges, we consider samples from all fourteen stations where dredge sampling recovered sediment and macrobenthic fauna. All the data used for the calculations were normalized to the same sampling volume. The diversity indices, i.e. taxonomic richness (number of taxa), Shannon index ( $H^{\prime}$, using $\log 2$ base and expressed in bits because this measure of diversity is derived from information theory) and Pielou's evenness $(\mathrm{J})$ are calculated from the collected fauna. A $k$-dominance curve is plotted to illustrate the quantitative distribution of the individuals among the taxa.

\subsection{Biological Traits of Life}

Biological Traits Analysis (BTA) is carried out on the recorded species as an alternative to studying the relative taxon composition (Bremner et al., 2003, 2006). Ten Biological Traits (BT) selected here cover different aspects of the life history, morphology and behaviour of each taxon: position on the substratum, habit, feeding mode, adult mobility, bioturbation, size, life span, developmental mechanisms, substratum preferences and ecological groups (Table 1). Each trait is divided into modalities (49 across the 10 studied traits) (Table 1). The significance of the selected BTs with regard to benthic functioning is discussed in Garcia (2010), Verisissimo et al. (2012) and Bolam and Eggleton (2014).

Information for assigning taxa to functional traits is obtained from various sources including the PhD thesis of Garcia (2010), the WORMS site (http://www.marinespecies.org; accessed on 15 September 2016), the UK Marlin site (http://www.marlin.ac.uk/biotic/; accessed on 15 September 2016), scientific journals and the scientific expertise of the authors. When reliable information is missing, data are considered from the phylogenetic nearest neighbour taxa. The resulting 'traits by station' data matrix is then submitted to multivariate analysis.

The Biological Traits Analysis is performed following the approach of Rigolet et al. (2014). The fuzzy coded 'species by trait' matrix is computed using a Fuzzy coded multiple analysis (FCA). The FCA output (coordinates of taxa on the first axes) is used to plot a dendrogram using Ward's linkage method based on Euclidean distances (Ward, 1963). Clusters of species exhibiting similar traits are then defined by selecting a given partitioning level. Finally, a biological profile is created for each cluster, showing for each trait the proportion of modalities exhibited by the cluster (Usseglio-Polatera et al., 2000). 
A total of 4,748 individuals are recorded from the 14 sampling stations. From standardized data expressed in terms of numbers of individuals per $1 \mathrm{~L}$ of sediment, we obtain a mean value of $170 \mathrm{ind} / \mathrm{L}$, while the numbers per station varies from 8.5 at station PT4 to 484 at station PT10 (Table 2). One mollusc taxon (Musculus discors) makes up more than 1,000 individuals among the collected fauna, while three amphipods (Elasmopus thalyae, Gammaropsis maculata and Maerella tenuimana) account for $>300$ individuals, five other taxa $>100$ individuals and 42 other taxa $\geq 10$ individuals. The eight dominant species represent $67 \%$ of the collection, while the amphipods represent $47 \%$ and the polychaetes 13

$\%$. Among the eight dominant species, there are seven crustaceans (five amphipods, one decapod and a Mysidae) and only one mollusc. The total number of taxa is 140, with 120 species, 17 genera and 3 taxa at a higher level of identification. Two zoological groups dominate: the crustaceans (69 taxa), which comprise the amphipods (33 species), and the polychaetes (48 taxa), including the Syllidae (14 taxa) (Fig. 3).

$\mathrm{H}^{\prime}$ is comprised between 0.25 (PT14) and 5.24 bits (Moul2), i.e. ranging from a poorly diversified to an extremely diverse community, with a mean value of 3.13 bits, i.e. the sampled community can be considered as very diverse.

$\mathrm{J}$ ' ranges between 0.08 (PT14) and 0.83 (PT4), i.e. station PT14 is dominated by one species and there is a large variation in community structure between species. J' shows a mean value of about 0.69 , i.e. the specimens are spread evenly between the different species.

The K-dominance curve (Fig. 4) shows the cumulative species abundance plotted against the log of species rank. It can be seen that the K-dominance curve has a typical sigmoidal shape indicating a balanced community of macroinvertebrates. Thus, no dominance of a single species can be observed, which means that the diversity increases along with the abundance of the macroinvertebrates.

\subsection{Biological Traits of Life}

The first two axes of the FCA account for more than $80 \%$ of the variability in biological trait composition (Fig. 5A). Correlation of traits along a given axis is relatively poor for the different axes used in this analysis. 

and PT14) is characterized by larger number of sessile epifauna species (fixed) that do not bioturbate, showing small size and direct larval development, with medium life-span and corresponding to sub-surface deposit-feeders. These species have an affinity with coarser sediment (pebbles) and are sensitive to disturbance. Group 3 is only observed at one station (PT29), being characterized by infaunal species, which are in most cases tolerant of disturbance, showing very small size and with a short life-span, corresponding to tube- or burrow-dwellers with diffusive activity (bioturbation) and characterized by direct larval development. These species have a preference for coarse mixed sediments and are mostly non-specific deposit-feeders. Group 2 clusters together all the other stations, and is made up of various species lacking any particular biological trait that can be discriminated by FCA (Figs. 5B and C).

\section{Discussion}

\subsection{General characteristics of the sampled fauna}

The benthic fauna recorded in this study area belongs to an extremely diverse community, without dominance of any particular species. The major groups of this fauna are made up of crustaceans, especially the amphipods, as well as polychaetes, in particular the Syllidae.

Before performing a biological traits analysis, much time and effort is needed to collate relevant data on species and ensure the availability of this information (Verissimo et al., 2012). In the present study, we succeeded in compiling a large and comprehensive database. Moreover, the large number of traits considered here lead to a more informative analysis (Bremner et al., 2006). The more commonly selected traits are "trophic groups" (for the description of community functioning) and "body size" (that gives an idea of the physical and life-history traits of species) (Paganelli et al., 2012). In the present study, we choose to add some traits that have been previously disregarded (because of a lack of information in the literature, Bremner et al., 2003; Paganelli et al., 2012), such as "larval development" or "lifespan", because we consider they are ecologically relevant. As with previous results obtained by Bremner et al. (2003, 2006), Marchini et al. (2008) or Pagenelli et al. (2012), the benthic community studied here is governed by traits related to lifestyle and behaviour of the species (trophic group, adult mobility, bioturbation, life habits and substratum affinity). Traits related to life-cycle properties (larval development and life-span) are moderately well correlated with 
FCA axes. This might be due to the dominance of single modalities, such as direct larval development (but well adapted for an area of high-energy hydrodynamics) or short life-span. The biological traits highlighted by this analysis of the Raz Blanchard benthic fauna are as follows: species of small size, belonging to the epifauna but living preferentially in burrows or tubes in coarse sediments (granules, pebbles and blocks), which participate in bioturbation of the site. The species may be mobile, probably to allow escape during periods of strong currents, and are mostly deposit-feeders (specialized or not) with a short life-span and showing a direct larval development. Finally, most of the sampled species are considered as sensitive to disturbance.

Gravels and coarse sand in the English Channel are known to have a diversified fauna, as observed in the Bay of Morlaix (1-mm mesh sieving) (Dauvin, 1988a, b). The mean value of diversity index $H^{\prime}$ in the Bay of Morlaix is lower than the mean value observed for coarse sediments in the eastern basin of the English Channel (mean value of 3.13 bits observed in the Raz Blanchard as compared to 4.33 bits in the English Channel; Foveau, 2009). The mean diversity index obtained for this site is comparable to values observed during the VIDEOCHARM surveys (Lozach, 2011). In areas with such strong hydrodynamic conditions, we might assume that food availability could be poor, with constant removal of fine-grained sediment that would cause abrasion on the species or prevent their settlement (Gray, 2002; Bigot, 2006). Thus, we would expect that this habitat is unable to support a rich community. For this reason, the species richness found in this area is considered as "surprisingly" diverse.

\subsection{New species for the western part of the English Channel}

A total of 350 individuals of the amphipod Elasmopus thalyae Gouillieux \& Sorbe, 2015 were collected from eight stations (Table 2). This species was first described on soft and hard bottoms in Arcachon Bay (France), and is found in the Raz Blanchard on three main substrates: gravel, pebbles and hard bottoms with sessile epifaunal turf (Foveau and Dauvin, 2017). This finding represents the northernmost localization of the species, which has been probably previously confused with the Mediterranean species Elasmopus rapax Costa 1853.

The amphipod Jassa herdmani (Walker, 1893) was previously known to exist only in the eastern part of the English Channel along the Opal coast (Dauvin, 1999). The present study is the first report of this species (13 individuals from four stations ranging from 40 to 64 $\mathrm{m}$ depth) in the western part of the English Channel. 
The tanaid Zeuxo holdichi (Bamber, 1990) was first described from Arcachon Bay by Bamber in 1990. This species has been recorded in Belgium and in the Netherlands since 2006 and in Germany since 2012, in coastal areas, on and between shells, on sediments, as well as on red seaweeds. This species is found in the Raz Blanchard at two gravelly stations (one specimen from each, at water depths of 51 to $64 \mathrm{~m}$ ), which represent one of the few subtidal locations of this species, most of the other identified sites being intertidal. It is the first report of occurrence in high-energy environments. Z. holdichi remains rare at most of the sampled locations, except at Luc-sur-Mer where the species is particularly abundant, although this occurrence remains enigmatic (Foveau et al., submitted).

The syllid species Prosphaerosyllis chauseyensis Olivier, Grant, San Martín, Archambault \& McKindsey, 2012 was recently described from a coarse sand intertidal habitat of the Chausey Islands (Olivier et al., 2012). A single individual was recorded at station PT9 at $50 \mathrm{~m}$ depth. This represents the deepest location of the species in the northern part of the NormanoBreton Gulf. The syllid Syllis columbretensis (Campoy, 1982) is known to range from the southern part of the Bay of Biscay to the eastern part of the Mediterranean Sea, and is recorded in the English Channel offshore Dieppe-Le Tréport on coarse sand (Pezy et al., in press). Many specimens were recorded during the monitoring of an artificial reef in the eastern Bay of Seine (Luc-sur-Mer beach, Foveau et al., 2015). A total of three individuals, all collected at station PT1, confirms the presence of this species in the English Channel.

\subsection{Consequences of the presence of mixed benthic habitats for the EUNIS Classification} and typology of marine habitats

The macrofauna recorded in the Raz Blanchard during the three sampling campaigns in 2015-2016 corresponds to the EUNIS habitat A4.13 'Mixed faunal turf communities on circalittoral rock' (EEA, 2006). This habitat type occurs on wave-exposed circalittoral bedrock and boulders, subject to tidal streams ranging from strong to moderately strong: 'This complex is characterised by its diverse range of hydroids (Halecium halecinum, Nemertesia antennina and Nemertesia ramosa), bryozoans (Alcyonidium diaphanum, Flustra foliacea, Bugula flabellata and Bugula plumosa) and sponges (Sycon ciliatum, Pachymatisma johnstonia, Cliona celata, Raspailia ramosa, Amphilectus fucorum (=Esperiopsis fucorum), Hemimycale columella and Dysidea fragilis) forming an often dense and mixed faunal turf. Other species found within this complex are Alcyonium digitatum, Urticina felina, Sagartia elegans, Actinothoe sphyrodeta, Caryophyllia smithii, Pomatoceros triqueter (=Pomatoceros 
triqueter), Balanus crenatus, Cancer pagurus, Necora puber, Asterias rubens, Echinus esculentus and Clavelina lepadiformis'.

As shown in the present study, the substrates and sediment characteristics of the Raz Blanchard area are highly variable, with the seabed showing a marked topographic heterogeneity, expressed mainly at a small scale by the presence of sediment patches in an overall rocky environment. Dauvin (2015) has suggested that the EUNIS habitat typology should be updated to take account of such variations in bed forms and mixed hard soft-bottom marine habitats. The investigations carried out by CEFAS on the English side of the Channel have also underlined the need to consider such mixed soft-hard bottoms (see Brown et al., 2002, 2004 a, b, 2011; Coggan and Diesing, 2012).

Hence, the macrofauna found in soft-bottom enclaves on the hard bottom correspond to two EUNIS habitats: respectively A5.1 Sublittoral coarse sediment and A5.14 Deep circalittoral coarse sediment. The first habitat type corresponds to coarse sediments including coarse sand, gravel, pebbles, shingle and cobbles, which are often unstable due to tidal currents and/or wave action. These habitats are generally found on the open coast or in tideswept channels of marine inlets. The second habitat type corresponds to offshore (deep) circalittoral environments with coarse sands and gravel or shells, and may cover large areas. Animal communities in this habitat are closely related to offshore mixed sediments, and settlement of Modiolus larvae may occur in some areas. Consequently, these habitats may occasionally contain large numbers of juvenile $M$. modiolus. The horse mussel $M$. modiolus was reported in some parts of the Raz Blanchard during the investigations carried out by Retière (1979), forming mussel beds in an area which corresponds to the southern limit of this species in this part of the English Channel. However, this species is not recorded at our sampling stations and its persistence in this area needs to be confirmed.

Described in the French Marine Benthic Habitats classification issued by the National Museum of Natural History (Paris) by Michez et al. (2015), the benthic habitats identified in our study correspond to three marine benthic communities:

1) Very mobile coarse infralittoral sediments with scattered fauna (Sédiments grossiers très mobiles infralittoraux à faune éparse);

2) Circalittoral pebbles under strong hydrodynamic conditions with scattered fauna (Cailloutis circalittoraux sous fort hydrodynamisme à faune éparse);

3) Mobile coastal circalittoral gravel and pebbles with Spirobranchus triqueter and Barnacles and encrusted Bryozoans) (Galets et cailloutis instables du circalittoral côtier à Spirobranchus triqueter avec Cirripèdes et Bryozoaires encroûtants). 
Our study demonstrates that neither the European EUNIS classification nor the French Marine Benthic Habitats classification are able to reflect the full variability of benthic assemblages, and that some updates need to be implemented in the future.

\section{Conclusions}

Although the benthic habitats of the Raz Blanchard have not been previously characterized, the fauna sampled here represents a highly diversified benthic community. The dominant groups of this community are crustaceans (particularly amphipods) and polychaetes (particularly Syllidae). The fauna is characterized by small species, living in interstitial position or as infauna or protected as in the case of erect hydrozoans. The species recorded here have adapted to this area of high-energy hydrodynamic conditions and hard irregular seabed. Adaptations may be morphological such as (1) development of a special body form to reduce friction; (2) reduction of body size, allowing the species to find protection in cracks; (3) body structures that enable temporary or permanent fixation, leading to improved footing or a reduction of structures serving for swimming; (4) increased body weight; (5) allocation of biomass to different organs physiologically conditioned by water flow) or behavioural (such as spending most of their life cycle within the substratum; mobility in protected areas or within the sediment; and (6) development of clear morphological adaptations for attachment. The community described here includes new species for the English Channel, and its recognition could lead to the implementation of future updates of the EUNIS classification.

\section{Acknowledgements}

The authors are grateful to the crews of the 'Celtic Warrior' and the 'Marie-Catherine' for their assistance in sampling operations. The results are derived from the PILE \& TIDE project, funded by the ADEME within the framework of the programme "Energies décarbonées des investissements du futur". The authors also thank M. Carpenter for the English revision.

\section{References}

Boillot, G., 1964. Géologie de la Manche occidentale: fonds rocheux, dépôts quaternaires, sédiments actuels. Ann. Inst. Océanogr. Paris 42, 1-219 
370

371

372

373

374

375

376

377

378

379

380

381

382

383

384

385

386

387

388

389

390

391

392

393

394

395

396

397

398

399

400

401

402

403

Bolam, S.G., Eggleton, J.D., 2014. Macrofaunal production and biological traits: spatial relationships along the UK continental shelf. J. Sea Res. 88, 47-58

Bremner, J., Rogers, S.I., Frid, C.L.J., 2003. Assessing functional diversity in marine benthic ecosystems: a comparison of approaches. Mar. Ecol. Prog. Ser. 254, 11-15

Bremner, J., Rogers, S.I., Frid, C.L.J., 2006. Matching biological traits to environmental conditions in marine benthic ecosystems. J. Mar. Syst. 60, 302-316

Bremner, J., 2008. Species' traits and ecological functioning in marine conservation and management. J. Exp. Mar. Bio. Ecol. 366, 37-47

Brown, C.J., Cooper, K.M., Meadows, W.J., Limpenny, D.S., Rees, H.L., 2002. Small-scale mapping of sea-bed assemblages in the Eastern English Channel using sidescan sonar and remote sampling techniques. Estuar. Coast. Mar. Sci. 54, 263-278

Brown, C.J., Hewer, A.J., Limpenny, D.S., Cooper, K.M., Rees, H.L., Meadows, W.J., 2004a. Mapping seabed biotopes using side scan sonar in regions of heterogeneous substrata: case study east of the Isle of Wight, English Channel. Underwater Technol. 26, 27-36

Brown, C.J., Hewer, A.J., Meadows, W.J., Limpenny, D.S., Cooper, K.M., Rees, H.L., 2004b. Mapping seabed biotopes at Hastings Shingle Bank, eastern English Channel. Part 1. Assessment using side scan sonar. J. Mar. Biol. Assoc. UK 84, 481-488

Brown, C.J., Smith, S.J., Lawton, P., Anderson, J.T., 2011. Benthic habitat mapping: a review of progress towards improved understanding of the spatial ecology of the seafloor using acoustic techniques. Estuar. Coast. Shelf Sci. 92, 502-520

Cabioch, L., 1968. Contribution à la connaissance des peuplements benthiques de la Manche occidentale. Cah. Biol. Mar. 9, 493-720

Coggan, R., Diesing, M., 2011. The seabed habitats of the central English Channel: a generation on from Holme and Cabioch, how do their interpretations match-up to modern mapping techniques? Cont. Shelf Res. 31, S132-S150

Coggan, R., Diesing, M., 2012. Rock ridges in the Central English Channel, in: Harris, P.T., Baker, E.K. (Eds.), Seafloor Geomorphology as Benthic Habitats. Elsevier, Amsterdam, pp. 471-480.

Dauvin, J.-C., 1988a. Structure et organisation trophique du peuplement des sables grossiers à Amphioxus lanceolatus - Venus fasciata de la baie de Morlaix (Manche Occidentale). Cah. Biol. Mar. 29, 163-185

Dauvin, J.-C., 1988b. Evolution temporelle (Août 1977- Août 1980) du peuplement des sables grossiers à Amphioxus lanceolatus-Venus fasciata de la baie de Morlaix (France). Oceanol. Acta 11, 173-183 
404

405

406

407

408

409

410

411

412

413

414

415

416

417

418

419

420

421

422

423

424

425

426

427

428

429

430

431

432

433

434

435

436

Dauvin, J.-C., 1999. Mise à jour de la liste des espèces d'Amphipodes (Crustacés Péracarides) présents en Manche. Cah. Biol. Mar. 40, 165-183

Dauvin, J.-C., 2015. History of benthic research in the English Channel: from general patterns of communities to habitat mosaic description. J. Sea Res. 100, 32-45

Diesing, M., Coggan, R., Vanstaen, K., 2009. Widespread rocky reef occurrence in the central English Channel and the implications for predictive habitat mapping. Estuar. Coast. Shelf Sci. $83,647-658$

Duffy, J.E., Stachowicz, J.J., 2006. Why biodiversity is important to oceanography: potential roles of genetic, species, and trophic diversity in pelagic ecosystem processes. Mar. Ecol. Prog. Ser. 311, 179-189

European Environmental Agency (EEA), 2006. EUNIS Habitat Classification, Version 2006 11. European Environmental Agency Copenhagen (internet application: http://eunis.eea.europa.eu/habitats.jsp)

Foveau, A., 2009. Habitats et communautés benthiques du bassin oriental de la Manche : état des lieux au début du XXIème siècle ( $\mathrm{PhD}$ thesis), University of Lille, France

Foveau, A., Dauvin, J.-C., Rusig, A.-M., Mussio, I., Claquin, P. 2015. Colonisation à courtterme par le benthos sur un éco-récif artificiel. In Congrès sur les récifs artificiels : des matériaux à l'écosystème / Congress on artificial reefs : from materials to ecosystems ESITC, Caen, $10 \mathrm{pp}$

Foveau, A., Dauvin, J.-C., 2017. Elasmopus thalyae (Crustacea: Amphipoda: Maeridae) in high energetic area off the North-west Cotentin peninsula, English Channel. Cah. Biol. Mar. $58(3)$

Foveau, A., Pezy, J.-P., Baux, N., Baffreau, A., Bachelet, Q., Chouquet, B., Dancie, C., Ruellet, T., Dauvin, J.-C., submitted. A new invasive species in the English Channel: the case of the tanaid Zeuxo holdichi. Cah. Biol. Mar.

Garcia, C., 2010. Approche fonctionnelle des communautés benthiques du bassin oriental de la Manche et du sud de la Mer du Nord (PhD thesis), University of Lille, France

Hommeril, P., 1967. Etude de géologie marine concernant le littoral bas-normand et la zone pré-littorale de l'archipel anglo-normand ( $\mathrm{PhD}$ thesis), University of Caen, France

Hooper, D.U., Chapin, F.S., Ewel, J.J., Hector, A., Inchausti, P., Lavorel, S., Lawton, J.H., Lodge, D.M., Loreau, M., Naeem, S., Schmid, B., Setala, H., Symstad, A.J., Vandermeer, J.,Wardle, D.A., 2005. Effects of biodiversity on ecosystem functioning: A consensus of current knowledge. Ecol. Monogr. 75, 3-35 
437

438

439

440

441

442

443

444

445

446

447

448

449

450

451

452

453

454

455

456

457

458

459

460

461

462

463

464

465

466

467

468

Larsonneur, C., Bouysse, P., Auffret, J.-P., 1982. The superficial sediments of the English Channel and its western approaches. Sedimentology 29, 851-864

Lozach, S., 2011. Habitats benthiques marins du basin oriental de la Manche : enjeux écologiques dans le contexte d'extraction de granulats marins ( $\mathrm{PhD}$ thesis), University of Lille, France

Marchini, A., Munari, C., Mistri, M., 2008. Functions and ecological status of eight Italian lagoons examined using biological traits analysis (BTA). Mar. Pollut. Bull. 56, 1076-1085

Menezes, S., Baird, D.J., Soares, A.M.V.M., 2010. Beyond taxonomy: a review of macroinvertebrate trait-based community descriptors as tools for freshwater biomonitoring. J. Appl. Ecol. 47, 711-719

Michez, N., Bajjouk, T., Aish, A., Andersen, A.C., Ar Gall, E., Baffreau, A., Blanchet, H., Chauvet, P., Dauvin, J.C., De Casamajor, M.N., Derrien-Courtel, S., Dubois, S., Fabri, M.C., Houbin, C., Legall, L., Menot, L., Rolet, C., Sauriau, P.G., Thiébaut, E., Tourolle, J., Van den Beld, I., 2015. Typologie des habitats marins benthiques de la Manche, de la Mer du Nord et de l'Atlantique Version 2. French Museum Report, SPN 2015 - 45, MNHN, Paris, p. 61.

Olivier, F., Grant, C., San Martín, G., Archambault, P., McKindsey, C.W., 2012. Syllidae (Annelida: Polychaeta: Phyllodocida) from the Chausey Archipelago (English Channel, France), with a description of two new species of the Exogoninae Prosphaerosyllis. Mar. Biodiv. 42, 55-63

Paganelli, D., Marchini, A., Occhipinti-Ambrogi, A., 2012. Functional structure of marine benthic assemblages using Biological Traits Analysis (BTA): A study along the EmiliaRomagna coastline (Italy, North-West Adriatic Sea). Estuar. Coast. Shelf Sci. 96, 245-256

Pezy, J.-P., Baffreau, A., Dauvin, J.-C., submitted. Revisited Syllidae of the English Channel coarse sand communities. J. Mar. Biol. Assoc. UK

Retière, C., 1979. Contribution à l'étude des peuplements benthiques du golfe NormanoBreton (PhD Thesis), Université of Rennes, France

Rigolet, C., Dubois, S., Thiébaut, E., 2014. Benthic control freaks: Effects of the tubiculous amphipod Haploops nirae on the specific diversity and functional structure of benthic communities. J. Sea Res. 85, 413-427

South East England Development Agency (SEEDA), 2007. Atlas of theTidal Energy

Resource on the South East Coast of England. Report of the Marine and Technical Marketing Consultants (MTMC) for the SEEDA, $31 \mathrm{pp}$ 
469 Thiébot, J., Bailly du Bois, P., Guillou, S., 2015. Numerical modelling of the effect of tidal 470 stream turbines on the hydrodynamics and the sediment transport - Application to the 471 Alderney Race (Raz Blanchard), France. Renew. Energ. 75, 356-365

472 Usseglio-Polater, P., Bournaud, M., Richoux, P., Tachet, H., 2000. Biological and ecological 473 traits of benthic freshwater macroinvertebrates: relationships and definition of group with 474 similar traits. Freshwater Biol. 43, 175-205

475 Van Haaren, T., Soors, J., 2009. Sinelobus stanfordi (Richardson, 1901): a new crustacean 476 invader in Europe. Aquat. Invasions 4, 703-711

477 Verissimo, H., Bremner, J., Garcia, C., Patricio, J., van der Linden, P., 2012. Assessment of 478 the subtidal macrobenthic community functioning of a temperate estuary following 479 environmental restoration. Ecol. Indic. 23, 312-322

480 Ward Jr, J.H., 1963. Hierarchical grouping to optimize an objective function. J. Am. Stat. 481 Assoc. 58, 236-244 


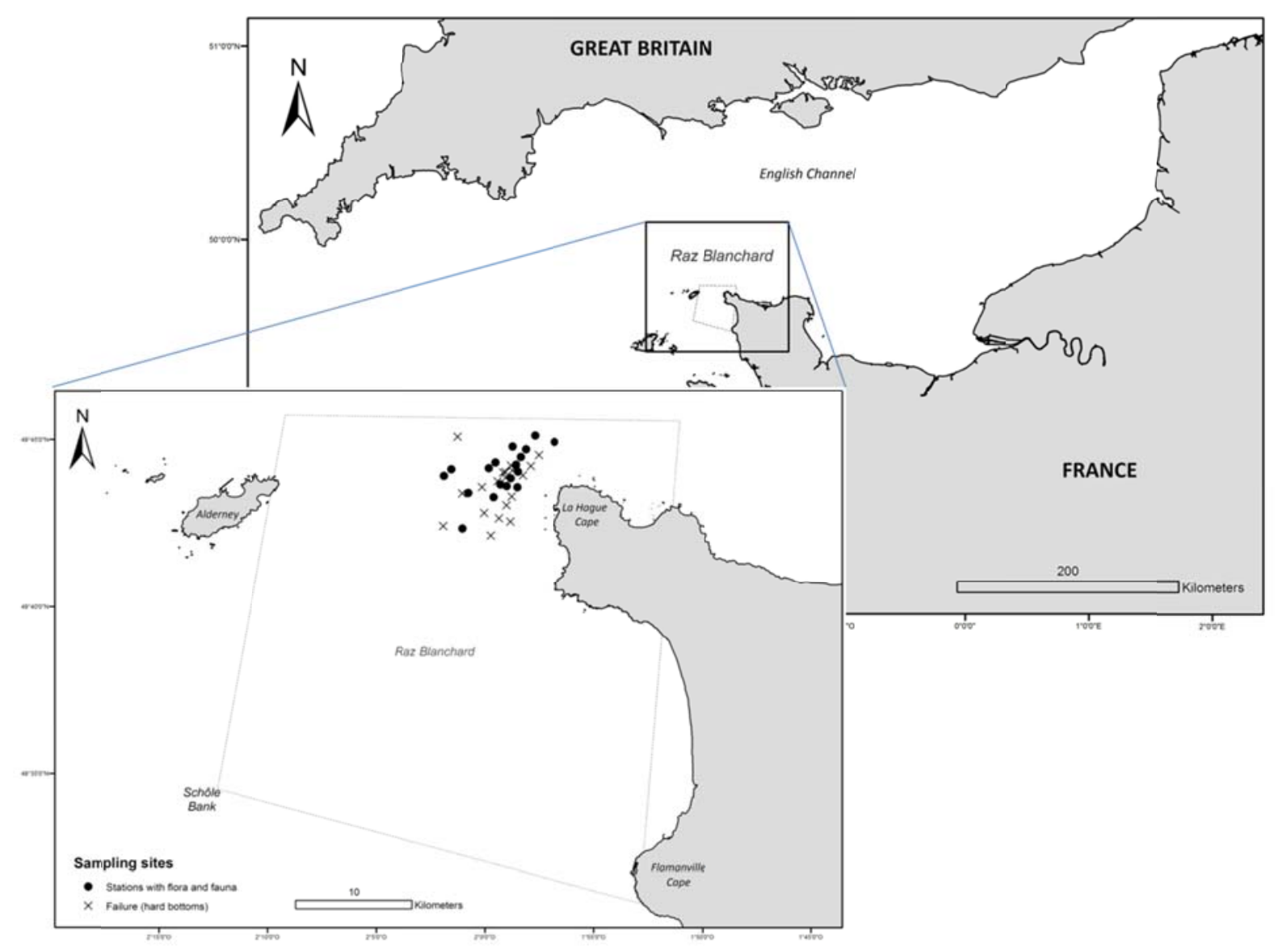




\section{ACCEPTED MANUSCRIPT}

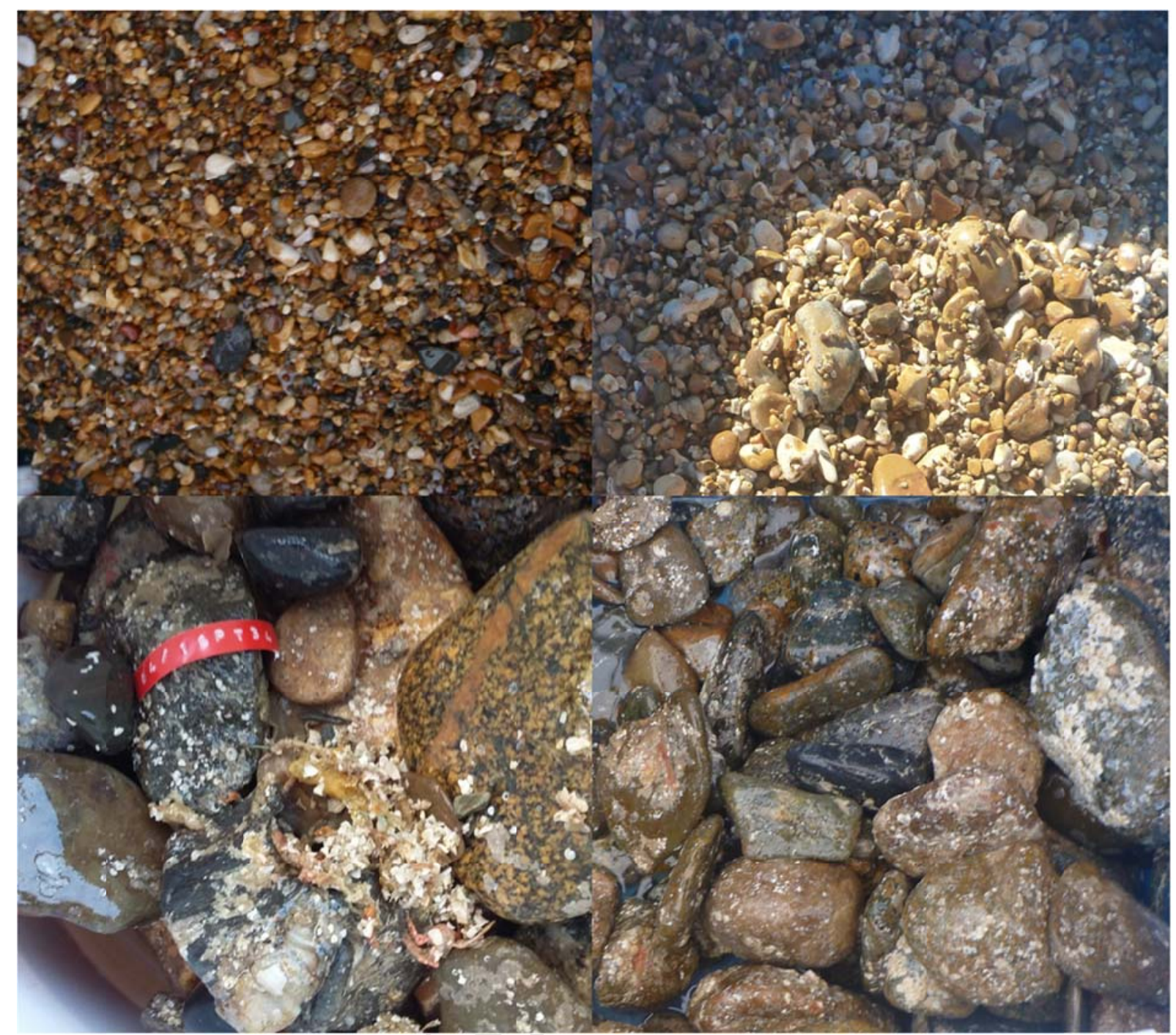

Figure 2. Images of sediments collected from the four main successful dredges (gravel, mix of

488

gravel and pebbles, pebbles). 


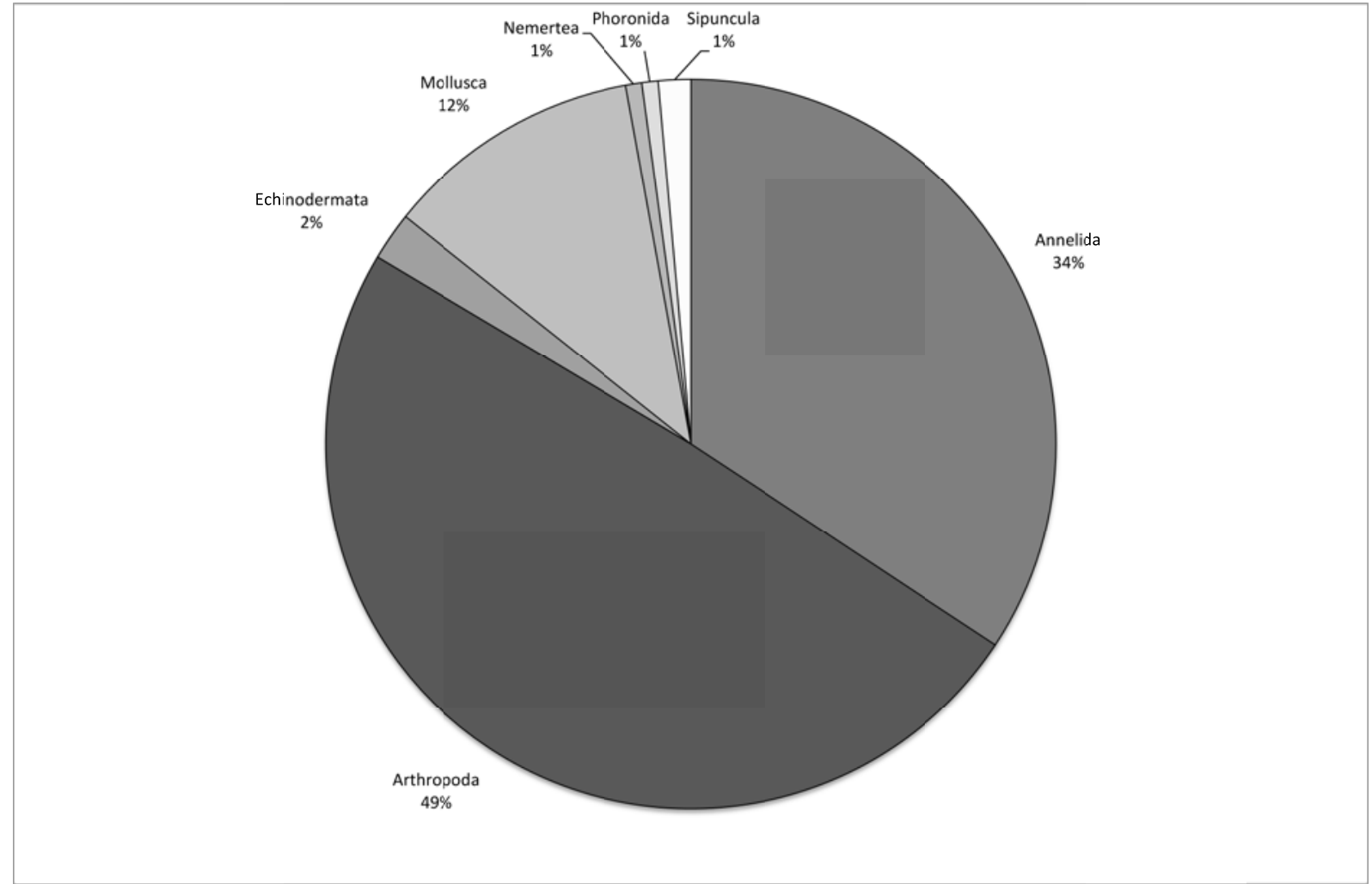

490

491

Figure 3. Distribution of the collected taxa in terms of main faunal groups. 


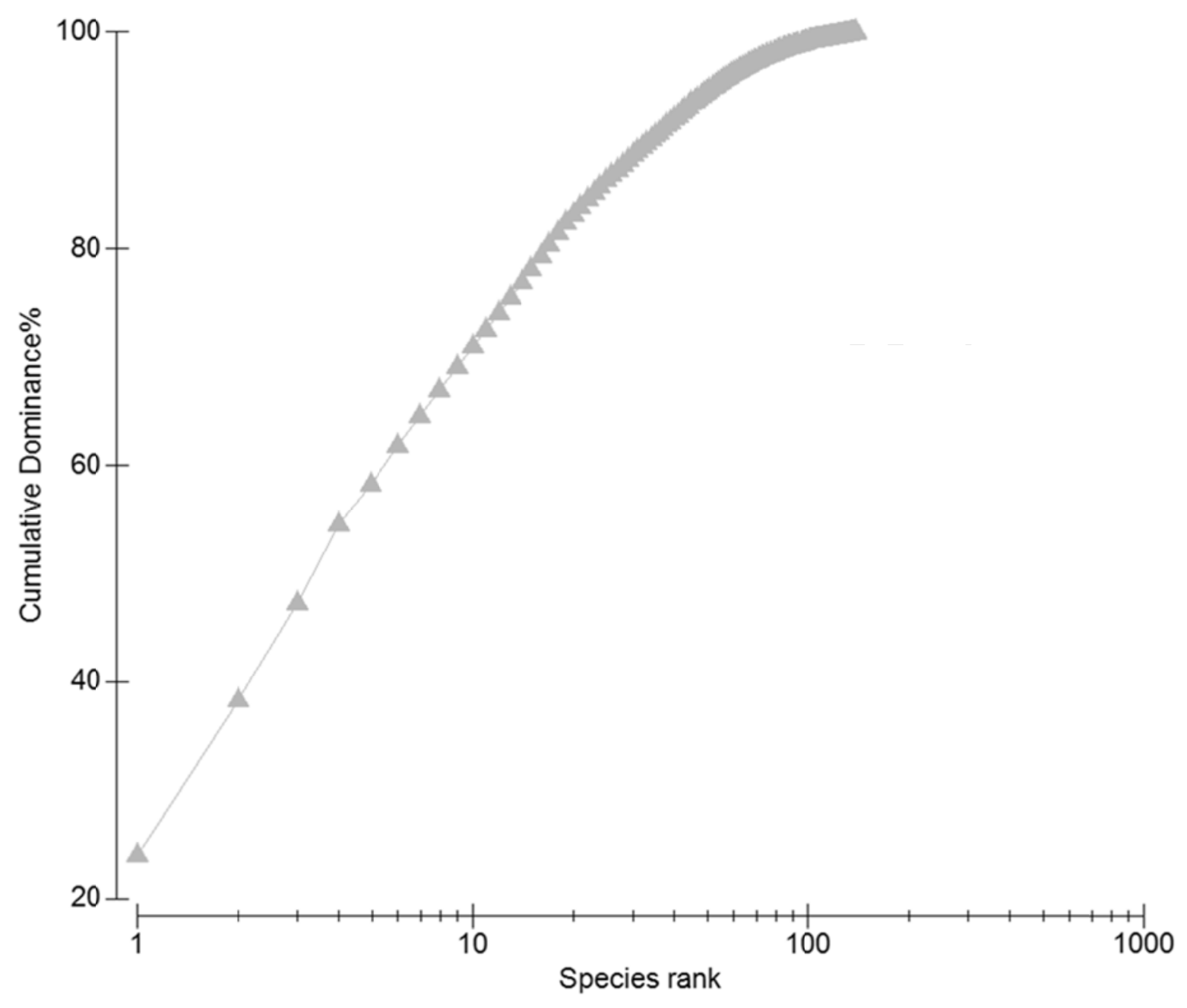

493

494 Figure 4. $k$-dominance curve of the total number of individuals recorded at the 14 stations. 495 


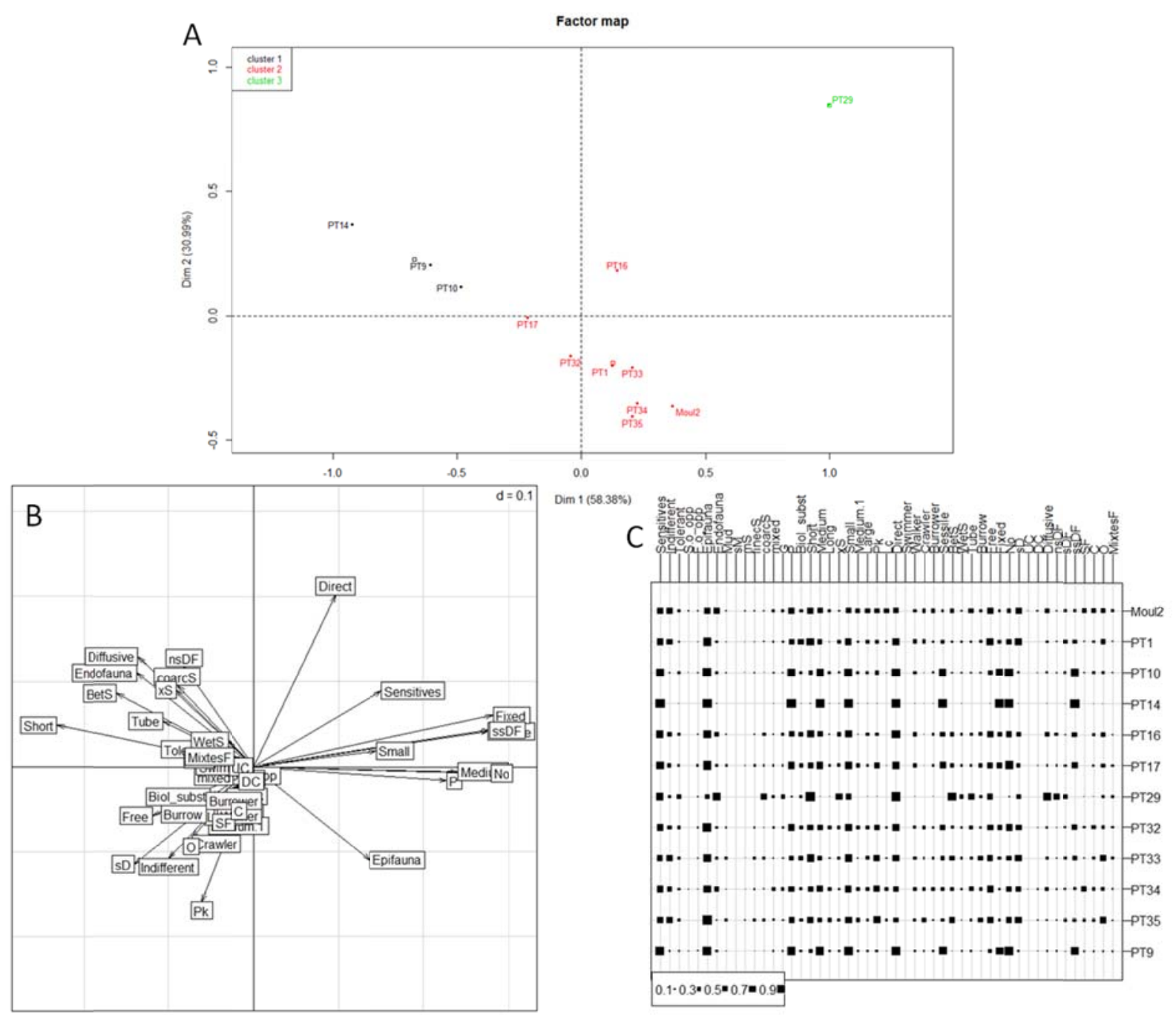

497 Figure 5. Results of FCA performed on the fauna (for species with more than 50 specimens 498 and discounting rare species) recorded from the 14 stations. 
Table 1. Biological traits and modalities of species selected for biological traits analysis

\begin{tabular}{|c|c|c|c|}
\hline Biological trait & $\mathbf{N}^{\circ}$ & Modality & Definition \\
\hline \multirow{3}{*}{ Larval development } & 1 & Planctotrophic & Planktonic larvae feeding on plankton \\
\hline & 2 & Lecithotrophic & Planktonic larvae feeding on yolk \\
\hline & 3 & Direct development & No planktonic larvae \\
\hline \multirow{3}{*}{ Life span } & 1 & Short & $<2$ years \\
\hline & 2 & Medium & $2-5$ years \\
\hline & 3 & Long & $>5$ years \\
\hline \multirow{7}{*}{ Mobility } & 1 & Swimmer & Adults actively swim in water column \\
\hline & 2 & Walker & Adults capable of extensive movement at sediment surface \\
\hline & 3 & Crawler & Adults with limited movements at sediment surface \\
\hline & 4 & Burrower & Endofauna that moves in the sediment \\
\hline & 5 & Sessile & Non-mobile adults (attached, limited to a tube or a burrow) \\
\hline & 6 & Burrower \& Swimmer & Benthic burrower species with nycthemeral migrations \\
\hline & 7 & Walker \& Swimmer & Benthic walker species with nycthemeral migrations \\
\hline \multirow{2}{*}{ Living position } & 1 & Epifauna & Live at the surface of the sediment \\
\hline & 2 & Endofauna & Live in the sediment \\
\hline \multirow{4}{*}{ Habit } & 1 & Tube-dweller & Adults builds tube \\
\hline & 2 & Burrow-dweller & Adults live in burrows (temporary or permanent) \\
\hline & 3 & Free-living & Adults not limited by a structure \\
\hline & 4 & Fixed & Adults live fixed on the substratum \\
\hline \multirow{5}{*}{ Bioturbation } & 1 & No bioturbation & Do not induce sediment displacement \\
\hline & 2 & Surface deposition & Surface displacement \\
\hline & 3 & Upward conveyor & Displacement of particles from depth to surface \\
\hline & 4 & Downward conveyor & Displacement of particles from surface to depth \\
\hline & 5 & Diffusive mixing & Small-scale displacement \\
\hline \multirow{7}{*}{ Trophic groups } & 1 & Non-specific deposit feeder & Feeds on particles at sediment surface and within the sediment \\
\hline & 2 & Surface deposit feeder & Feeds on particles at sediment's surface \\
\hline & 3 & Sub-surface deposit feeder & Feeds on particles within the sediment \\
\hline & 4 & Suspension feeder & Feeds on particles within the water column \\
\hline & 5 & Carnivorous & Feeds on live prey \\
\hline & 6 & Omnivorous & Generalist feeder \\
\hline & 7 & Mixtes & Feeds on particles in the water column and at sediments' surface \\
\hline \multirow{5}{*}{ Ecological groups (AMBI) } & 1 & Sensitives & Only present in unpolluted areas \\
\hline & 2 & Indifferent & Always present at low densities \\
\hline & 3 & Tolerant & More abundant in slightly enriched areas \\
\hline & 4 & Second-order opportunists & Present in unbalanced conditions \\
\hline & 5 & First-order opportunists & Proliferate in reduced sediment \\
\hline \multirow{9}{*}{ Substratum affinity } & 1 & Mud & Particles $<63 \mu \mathrm{m}$ are present or dominant \\
\hline & 2 & Sandy mud & $50 \%$ to $<90 \%$ sand, mud remainder \\
\hline & 3 & Muddy sand & $10 \%$ to $<50 \%$ sand; mud remainder \\
\hline & 4 & Fine clean sand & $>90 \%$ sand, median 0.125 to $<0.25 \mathrm{~mm}$ \\
\hline & 5 & Coarse clean sand & $>90 \%$ sand, median 0.500 to $<1 \mathrm{~mm}$ \\
\hline & 6 & Mixed sediments & Mix of different sediments \\
\hline & 7 & Granules & Particles between 1 and $2 \mathrm{~mm}$ \\
\hline & 8 & Pebbles, rocks and hard substratum & Particles between 2 and $64 \mathrm{~mm}$ \\
\hline & 9 & Biological substratum & Adults live on living organisms \\
\hline \multirow{4}{*}{ Maximal size } & 1 & Very small & $<10 \mathrm{~mm}$ \\
\hline & 2 & Small & 10 to $20 \mathrm{~mm}$ \\
\hline & 3 & Medium & 21 to $100 \mathrm{~mm}$ \\
\hline & 4 & Large & $>100 \mathrm{~mm}$ \\
\hline
\end{tabular}


Table 2. List of taxa recorded from the 14 stations classified by phylum. Total number of

\begin{tabular}{|c|c|c|c|c|c|c|c|c|c|c|c|c|c|c|c|}
\hline Phylum & Taxa & Moul2 & PT1 & PT4 & PT9 & PT10 & PT11 & PT14 & PT16 & PT17 & PT29 & PT32 & PT33 & PT34 & PT35 \\
\hline \multirow{48}{*}{ Annelida } & Amblyosyllis $s p$. & 0 & 1 & 0 & 0 & 0 & 0 & 0 & 0 & 0 & 0 & 0 & 0 & 1 & 0 \\
\hline & Autolytinae & 38 & 0 & 0 & 0 & 0 & 0 & 0 & 0 & 0 & 0 & 6 & 1 & 8 & 3 \\
\hline & Boccardia polybranchia & 0 & 0 & 0 & 0 & 1 & 0 & 0 & 0 & 0 & 0 & 0 & 0 & 0 & 0 \\
\hline & Branchiomma bombyx & 0 & 0 & 0 & 0 & 0 & 0 & 0 & 0 & 0 & 0 & 0 & 0 & 1 & 0 \\
\hline & Cirratulus cirratus & 5 & 0 & 0 & 0 & 0 & 1 & 0 & 0 & 0 & 0 & 0 & 0 & 3 & 0 \\
\hline & Eumida sanguinea & 2 & 0 & 0 & 0 & 0 & 0 & 0 & 0 & 0 & 0 & 0 & 0 & 0 & 0 \\
\hline & Eunoe nodosa & 0 & 0 & 0 & 0 & 1 & 0 & 0 & 0 & 0 & 0 & 0 & 0 & 0 & 0 \\
\hline & Euphrosine foliosa & 2 & 0 & 0 & 0 & 0 & 0 & 0 & 0 & 0 & 0 & 0 & 0 & 2 & 1 \\
\hline & Eupolymnia nebulosa & 27 & 0 & 0 & 0 & 0 & 0 & 0 & 0 & 0 & 0 & 1 & 0 & 6 & 0 \\
\hline & Eurysyllis tuberculata & 2 & 0 & 0 & 0 & 0 & 0 & 0 & 0 & 0 & 0 & 0 & 0 & 0 & 0 \\
\hline & Glycera lapidum & 1 & 0 & 0 & 0 & 0 & 0 & 0 & 0 & 0 & 0 & 0 & 0 & 0 & 0 \\
\hline & Haplosyllis spongicola & 1 & 0 & 0 & 1 & 4 & 0 & 0 & 0 & 0 & 0 & 0 & 0 & 1 & 0 \\
\hline & Harmothoe spp. & 11 & 0 & 0 & 0 & 0 & 0 & 0 & 0 & 0 & 1 & 0 & 0 & 2 & 0 \\
\hline & Jasmineira elegans & 74 & 1 & 0 & 0 & 0 & 0 & 0 & 0 & 0 & 0 & 0 & 0 & 26 & 0 \\
\hline & Lanice conchilega & 1 & 0 & 0 & 2 & 3 & 1 & 0 & 0 & 1 & 0 & 0 & 0 & 5 & 1 \\
\hline & Lepidonotus squamatus & 2 & 0 & 0 & 0 & 2 & 0 & 0 & 0 & 0 & 0 & 0 & 0 & 2 & 0 \\
\hline & Lumbrineris latreilli & 1 & 0 & 0 & 0 & 0 & 0 & 0 & 0 & 0 & 0 & 0 & 0 & 0 & 0 \\
\hline & Lysidice ninetta & 2 & 1 & 0 & 0 & 0 & 0 & 0 & 0 & 0 & 0 & 0 & 0 & 2 & 0 \\
\hline & Lysidice unicornis & 4 & 0 & 0 & 0 & 0 & 1 & 0 & 0 & 0 & 0 & 0 & 0 & 5 & 0 \\
\hline & Myrianida sp. & 0 & 0 & 0 & 0 & 0 & 0 & 2 & 0 & 0 & 0 & 0 & 0 & 0 & 0 \\
\hline & Mysta picta & 6 & 0 & 0 & 0 & 0 & 0 & 0 & 0 & 0 & 0 & 0 & 0 & 1 & 0 \\
\hline & Odontosyllis fulgurans & 0 & 0 & 0 & 0 & 3 & 0 & 0 & 3 & 0 & 0 & 0 & 0 & 0 & 0 \\
\hline & Pherusa plumosa & 1 & 0 & 0 & 0 & 0 & 0 & 0 & 0 & 0 & 0 & 0 & 0 & 0 & 0 \\
\hline & Pholoe sp. & 1 & 0 & 0 & 0 & 0 & 0 & 0 & 0 & 0 & 0 & 0 & 0 & 0 & 0 \\
\hline & Polycirrus sp. & 2 & 0 & 0 & 3 & 2 & 0 & 0 & 0 & 0 & 0 & 0 & 0 & 3 & 0 \\
\hline & Polydora ciliata & 18 & 0 & 0 & 0 & 0 & 0 & 0 & 0 & 0 & 0 & 0 & 0 & 0 & 0 \\
\hline & Polygordius sp. & 10 & 0 & 0 & 0 & 0 & 0 & 0 & 0 & 0 & 0 & 0 & 0 & 0 & 0 \\
\hline & Polynoe scolopendrina & 2 & 0 & 0 & 0 & 0 & 0 & 0 & 0 & 0 & 0 & 0 & 0 & 1 & 0 \\
\hline & Proceraea sp. & 4 & 2 & 0 & 0 & 0 & 0 & 0 & 0 & 0 & 0 & 0 & 0 & 0 & 0 \\
\hline & Prosphaerosyllis chauseyensis & 0 & 0 & 0 & 1 & 0 & 0 & 0 & 0 & 0 & 0 & 0 & 0 & 0 & 0 \\
\hline & Psamathe fusca & 0 & 0 & 0 & 2 & 0 & 0 & 1 & 0 & 0 & 0 & 0 & 0 & 0 & 0 \\
\hline & Pseudopotamilla reniformis & 6 & 1 & 0 & 0 & 2 & 1 & 0 & 0 & 0 & 0 & 0 & 0 & 6 & 0 \\
\hline & Sabella pavonina & 0 & 0 & 0 & 1 & 0 & 0 & 0 & 0 & 0 & 0 & 0 & 0 & 0 & 0 \\
\hline & Sabellaria spinulosa & 39 & 0 & 0 & 0 & 0 & 0 & 0 & 0 & 0 & 0 & 0 & 0 & 26 & 2 \\
\hline & Schistomeringos sp. & 1 & 0 & 0 & 0 & 0 & 0 & 0 & 0 & 0 & 0 & 0 & 0 & 0 & 0 \\
\hline & Sphaerosyllis bulbosa & 3 & 0 & 0 & 0 & 0 & 0 & 0 & 0 & 0 & 0 & 0 & 0 & 0 & 0 \\
\hline & Spio martinensis & 2 & 0 & 0 & 0 & 0 & 0 & 0 & 0 & 0 & 0 & 0 & 0 & 0 & 0 \\
\hline & Spirobranchus triqueter & 2 & 1 & 0 & 0 & 0 & 0 & 0 & 0 & 0 & 0 & 1 & 0 & 0 & 0 \\
\hline & Syllis armillaris & 28 & 0 & 0 & 1 & 0 & 1 & 0 & 0 & 0 & 0 & 0 & 0 & 0 & 0 \\
\hline & Syllis columbretensis & 0 & 3 & 0 & 0 & 0 & 0 & 0 & 0 & 0 & 0 & 0 & 0 & 0 & 0 \\
\hline & Syllis gracilis & 5 & 4 & 0 & 0 & 0 & 0 & 0 & 0 & 0 & 0 & 0 & 0 & 0 & 0 \\
\hline & Syllis hyalina & 14 & 0 & 0 & 1 & 0 & 0 & 0 & 0 & 0 & 0 & 0 & 0 & 0 & 0 \\
\hline & Syllis variegata & 8 & 0 & 0 & 0 & 1 & 0 & 0 & 0 & 0 & 0 & 0 & 0 & 1 & 0 \\
\hline & Syllis vittata & 0 & 1 & 0 & 0 & 0 & 0 & 0 & 0 & 0 & 0 & 1 & 1 & 19 & 0 \\
\hline & Thelepus setosus & 5 & 0 & 0 & 0 & 0 & 0 & 0 & 0 & 0 & 0 & 0 & 0 & 2 & 0 \\
\hline & Trypanosyllis (Trypanosyllis) coeliaca & 2 & 0 & 0 & 0 & 0 & 0 & 0 & 0 & 0 & 0 & 0 & 0 & 1 & 0 \\
\hline & Trypanosyllis zebra & 1 & 0 & 0 & 0 & 0 & 0 & 0 & 0 & 0 & 0 & 0 & 0 & 1 & 0 \\
\hline & Websterinereis glauca & 55 & 1 & 0 & 0 & 1 & 0 & 0 & 0 & 0 & 0 & 0 & 2 & 17 & 0 \\
\hline \multirow{3}{*}{ Echinodermata } & Amphipholis squamata & 17 & 0 & 0 & 0 & 0 & 0 & 0 & 0 & 0 & 0 & 1 & 0 & 11 & 2 \\
\hline & Asterina gibbosa & 6 & 0 & 0 & 0 & 0 & 0 & 0 & 0 & 0 & 0 & 1 & 0 & 3 & 5 \\
\hline & Ophiothrix fragilis & 7 & 0 & 0 & 5 & 2 & 0 & 0 & 0 & 0 & 1 & 2 & 0 & 7 & 1 \\
\hline \multirow{16}{*}{ Mollusca } & Acanthochitona crinita & 0 & 0 & 0 & 0 & 0 & 0 & 0 & 0 & 0 & 0 & 0 & 0 & 1 & 0 \\
\hline & Aeolidia papillosa & 0 & 0 & 0 & 0 & 0 & 0 & 0 & 0 & 0 & 0 & 0 & 0 & 1 & 0 \\
\hline & Berthella plumula & 2 & 0 & 0 & 0 & 0 & 0 & 0 & 0 & 0 & 0 & 0 & 0 & 0 & 0 \\
\hline & Buccinum undatum & 0 & 0 & 0 & 0 & 0 & 0 & 0 & 0 & 0 & 0 & 0 & 0 & 0 & 1 \\
\hline & Emarginula rosea & 2 & 0 & 0 & 0 & 0 & 0 & 0 & 0 & 0 & 0 & 0 & 0 & 1 & 0 \\
\hline & Gibbula cineraria & 2 & 1 & 0 & 0 & 0 & 0 & 0 & 0 & 0 & 0 & 0 & 1 & 4 & 1 \\
\hline & Jujubinus montagui & 4 & 2 & 0 & 0 & 0 & 0 & 0 & 0 & 0 & 0 & 0 & 0 & 1 & 0 \\
\hline & Musculus discors & 35 & 24 & 8 & 156 & 309 & 17 & 478 & 18 & 28 & 1 & 17 & 19 & 23 & 8 \\
\hline & Nucella lapillus & 0 & 0 & 0 & 0 & 0 & 0 & 1 & 0 & 0 & 0 & 0 & 0 & 0 & 0 \\
\hline & Ocenebra erinacea & 13 & 0 & 0 & 0 & 0 & 0 & 0 & 0 & 0 & 0 & 0 & 0 & 8 & 0 \\
\hline & Onchidoris bilamellata & 0 & 0 & 0 & 0 & 0 & 0 & 0 & 0 & 0 & 0 & 1 & 0 & 0 & 0 \\
\hline & Pleurobranchus membranaceus & 4 & 0 & 0 & 0 & 0 & 0 & 0 & 0 & 0 & 0 & 0 & 0 & 1 & 0 \\
\hline & Rissoa parva & 11 & 11 & 0 & 1 & 0 & 1 & 0 & 1 & 1 & 0 & 2 & 5 & 6 & 3 \\
\hline & Sphenia binghami & 5 & 0 & 0 & 0 & 0 & 0 & 0 & 0 & 0 & 0 & 0 & 1 & 4 & 0 \\
\hline & Tricolia pullus & 10 & 6 & 0 & 0 & 2 & 0 & 1 & 0 & 0 & 0 & 0 & 1 & 1 & 1 \\
\hline & Tritonia hombergii & 0 & 0 & 0 & 0 & 0 & 0 & 0 & 0 & 0 & 0 & 0 & 0 & 1 & 0 \\
\hline Nemertea & Tubulanus $s p$. & 16 & 0 & 0 & 0 & 1 & 0 & 0 & 0 & 0 & 0 & 0 & 3 & 5 & 0 \\
\hline Phoronida & Phoronis sp. & 0 & 0 & 0 & 0 & 0 & 0 & 1 & 0 & 0 & 0 & 0 & 0 & 0 & 0 \\
\hline \multirow{2}{*}{ Sipuncula } & Golfingia (Golfingia) vulgaris vulgaris & 7 & 0 & 0 & 0 & 0 & 0 & 0 & 0 & 0 & 0 & 0 & 1 & 2 & 0 \\
\hline & Phascolion (Phascolion) strombus strombus & 0 & 0 & 0 & 0 & 0 & 0 & 0 & 0 & 1 & 0 & 0 & 0 & 0 & 1 \\
\hline
\end{tabular}


Table 2 (continued). List of taxa recorded from the 14 stations classified by phylum. Total

508 number of individuals per station, number of taxa, Shannon diversity index (H'), Pielou's evenness $(\mathrm{J})$ and volume of sediment in each dredge are given at bottom of table.

\begin{tabular}{|c|c|c|c|c|c|c|c|c|c|c|c|c|c|c|c|}
\hline Phylum & Taxa & Moul2 & PT1 & PT4 & PT9 & PT10 & PT11 & PT14 & PT16 & PT17 & PT29 & PT32 & PT33 & PT34 & PT35 \\
\hline & Abludomelita gladiosa & 2 & 0 & 0 & 0 & 0 & 0 & 0 & 0 & 0 & 0 & 0 & 0 & 0 & 0 \\
\hline & Abludomelita obtusata & 1 & 1 & 0 & 0 & 0 & 0 & 0 & 0 & 0 & 0 & 0 & 0 & 0 & 0 \\
\hline & Achelia echinata & 0 & 0 & 0 & 0 & 0 & 0 & 0 & 0 & 0 & 0 & 1 & 0 & 0 & 0 \\
\hline & Achelia hispida & 0 & 0 & 0 & 0 & 1 & 0 & 0 & 0 & 0 & 0 & 0 & 0 & 0 & 0 \\
\hline & Ampelisca spinipes & 1 & 0 & 0 & 0 & 0 & 0 & 0 & 0 & 0 & 0 & 0 & 0 & 0 & 0 \\
\hline & Amphilochidae & 0 & 0 & 0 & 0 & 5 & 0 & 0 & 0 & 0 & 0 & 0 & 0 & 0 & 0 \\
\hline & Ampithoe rubricata & 0 & 0 & 0 & 1 & 0 & 0 & 0 & 0 & 0 & 0 & 0 & 0 & 0 & 0 \\
\hline & Anapagurus hyndmanni & 0 & 0 & 0 & 0 & 0 & 0 & 0 & 0 & 0 & 0 & 0 & 0 & 1 & 0 \\
\hline & Animoceradocus semiserratus & 0 & 0 & 0 & 0 & 0 & 0 & 0 & 1 & 0 & 58 & 0 & 0 & 0 & 0 \\
\hline & Anthura gracilis & 1 & 0 & 0 & 0 & 0 & 0 & 0 & 0 & 0 & 0 & 0 & 0 & 0 & 0 \\
\hline & Apherusa bispinosa & 0 & 0 & 0 & 0 & 0 & 0 & 0 & 1 & 0 & 0 & 1 & 1 & 0 & 0 \\
\hline & Apherusa jurinei & 0 & 2 & 0 & 1 & 11 & 2 & 4 & 0 & 2 & 0 & 0 & 0 & 0 & 0 \\
\hline & Astacilla longicornis & 0 & 1 & 0 & 0 & 0 & 0 & 0 & 0 & 0 & 0 & 0 & 0 & 0 & 0 \\
\hline & Axius stirhynchus & 0 & 0 & 1 & 2 & 10 & 2 & 0 & 0 & 0 & 0 & 0 & 0 & 0 & 0 \\
\hline & Bodotria scorpioides & 11 & 0 & 0 & 0 & 0 & 0 & 0 & 0 & 0 & 0 & 0 & 0 & 7 & 0 \\
\hline & Cancer pagurus & 0 & 0 & 1 & 4 & 45 & 1 & 1 & 2 & 4 & 5 & 4 & 3 & 1 & 2 \\
\hline & Caprella penantis & 13 & 18 & 1 & 0 & 1 & 0 & 0 & 7 & 1 & 0 & 0 & 6 & 3 & 1 \\
\hline & Caprella tuberculata & 1 & 8 & 0 & 2 & 0 & 0 & 0 & 2 & 0 & 0 & 1 & 0 & 0 & 0 \\
\hline & Cirolana cranchi & 1 & 0 & 0 & 0 & 0 & 0 & 0 & 0 & 0 & 0 & 0 & 0 & 1 & 0 \\
\hline & Colomastix pusilla & 0 & 0 & 0 & 0 & 0 & 0 & 0 & 0 & 0 & 0 & 0 & 0 & 1 & 0 \\
\hline & Cyathura carinata & 1 & 0 & 0 & 0 & 0 & 0 & 0 & 0 & 0 & 1 & 0 & 0 & 0 & 0 \\
\hline & Dexamine spinosa & 0 & 0 & 0 & 0 & 0 & 0 & 0 & 1 & 0 & 0 & 0 & 3 & 0 & 0 \\
\hline & Dynamene bidentata & 0 & 0 & 0 & 0 & 0 & 0 & 0 & 0 & 0 & 0 & 0 & 0 & 1 & 0 \\
\hline & Dyopedos porrectus & 1 & 0 & 2 & 0 & 5 & 1 & 0 & 0 & 0 & 0 & 3 & 3 & 12 & 4 \\
\hline & Elasmopus thalyae & 9 & 2 & 2 & 0 & 2 & 0 & 0 & 3 & 0 & 327 & 0 & 2 & 3 & 0 \\
\hline & Ericthonius punctatus & 0 & 0 & 0 & 0 & 0 & 0 & 0 & 0 & 0 & 1 & 0 & 0 & 1 & 0 \\
\hline & Eurydice spinigera & 0 & 0 & 0 & 1 & 0 & 0 & 0 & 0 & 0 & 0 & 0 & 0 & 0 & 0 \\
\hline & Eurynome aspera & 0 & 0 & 0 & 0 & 0 & 0 & 0 & 0 & 0 & 0 & 0 & 0 & 1 & 0 \\
\hline & Galathea squamifera & 1 & 0 & 0 & 0 & 0 & 0 & 0 & 1 & 0 & 0 & 0 & 0 & 2 & 0 \\
\hline & Gammaropsis maculata & 9 & 0 & 0 & 0 & 0 & 0 & 0 & 0 & 0 & 413 & 0 & 0 & 0 & 0 \\
\hline & Gnathia dentata & 3 & 0 & 0 & 0 & 0 & 0 & 0 & 0 & 0 & 0 & 0 & 0 & 0 & 0 \\
\hline & Gnathia maxillaris & 0 & 0 & 0 & 0 & 0 & 0 & 0 & 0 & 0 & 0 & 1 & 0 & 3 & 0 \\
\hline & Inachus sp. & 0 & 0 & 0 & 0 & 0 & 0 & 0 & 0 & 0 & 1 & 0 & 0 & 0 & 0 \\
\hline & Iphimedia minuta & 1 & 0 & 0 & 0 & 0 & 0 & 0 & 0 & 0 & 0 & 0 & 0 & 0 & 0 \\
\hline \multirow[t]{40}{*}{ Arthropoda } & Janira maculosa & 10 & 1 & 0 & 0 & 2 & 0 & 0 & 0 & 0 & 1 & 1 & 0 & 4 & 0 \\
\hline & Jassa falcata & 8 & 1 & 0 & 0 & 2 & 0 & 0 & 1 & 1 & 44 & 2 & 4 & 6 & 0 \\
\hline & Jassa herdmani & 0 & 0 & 0 & 6 & 3 & 1 & 0 & 0 & 3 & 0 & 0 & 0 & 0 & 0 \\
\hline & Leptocheirus hirsutimanus & 0 & 0 & 0 & 1 & 0 & 0 & 0 & 0 & 0 & 129 & 0 & 0 & 0 & 0 \\
\hline & Leucothoe $s p$. & 1 & 0 & 0 & 0 & 0 & 0 & 0 & 0 & 0 & 0 & 0 & 0 & 0 & 0 \\
\hline & Liljeborgia pallida & 1 & 0 & 0 & 0 & 0 & 0 & 0 & 0 & 0 & 0 & 0 & 0 & 1 & 0 \\
\hline & Liocarcinus sp. & 0 & 0 & 0 & 0 & 0 & 0 & 0 & 0 & 0 & 0 & 0 & 0 & 1 & 0 \\
\hline & Macropodia sp. & 0 & 0 & 0 & 0 & 0 & 0 & 0 & 0 & 5 & 0 & 0 & 0 & 0 & 0 \\
\hline & Maerella tenuimana & 0 & 0 & 0 & 0 & 0 & 0 & 0 & 3 & 0 & 675 & 0 & 0 & 0 & 0 \\
\hline & Metopa alderi & 0 & 0 & 0 & 0 & 1 & 0 & 0 & 0 & 0 & 0 & 0 & 0 & 0 & 0 \\
\hline & Metopa tenuimana & 0 & 3 & 0 & 0 & 0 & 0 & 0 & 0 & 0 & 1 & 0 & 0 & 0 & 0 \\
\hline & Microdeutopus anomalus & 0 & 0 & 0 & 6 & 0 & 0 & 0 & 0 & 0 & 0 & 0 & 0 & 0 & 0 \\
\hline & Monocorophium sextonae & 11 & 1 & 0 & 0 & 0 & 0 & 0 & 0 & 0 & 0 & 0 & 0 & 1 & 0 \\
\hline & Mysida & 42 & 4 & 0 & 0 & 0 & 2 & 0 & 1 & 7 & 0 & 3 & 22 & 17 & 18 \\
\hline & Nototropis swammerdamei & 40 & 3 & 1 & 1 & 7 & 2 & 2 & 0 & 0 & 2 & 2 & 2 & 25 & 0 \\
\hline & Othomaera othonis & 0 & 0 & 0 & 0 & 0 & 0 & 0 & 3 & 0 & 0 & 0 & 0 & 5 & 0 \\
\hline & Pagurus sp. & 0 & 0 & 0 & 2 & 0 & 0 & 0 & 0 & 2 & 0 & 0 & 0 & 0 & 0 \\
\hline & Palaemon serratus & 1 & 0 & 0 & 0 & 0 & 0 & 0 & 0 & 0 & 0 & 0 & 0 & 0 & 0 \\
\hline & Pandalina brevirostris & 0 & 0 & 0 & 0 & 0 & 0 & 0 & 0 & 0 & 0 & 0 & 0 & 7 & 1 \\
\hline & Parapleustes bicuspis & 0 & 0 & 0 & 8 & 5 & 0 & 0 & 0 & 1 & 0 & 0 & 0 & 0 & 0 \\
\hline & Phtisica marina & 0 & 0 & 0 & 0 & 0 & 1 & 0 & 0 & 0 & 0 & 0 & 0 & 0 & 0 \\
\hline & Pilumnus hirtellus & 8 & 0 & 0 & 0 & 1 & 0 & 0 & 0 & 0 & 0 & 1 & 1 & 4 & 0 \\
\hline & Pinnotheres pisum & 1 & 0 & 0 & 0 & 0 & 0 & 0 & 0 & 0 & 0 & 0 & 0 & 0 & 0 \\
\hline & Pisa sp. & 0 & 0 & 2 & 5 & 35 & 3 & 0 & 0 & 6 & 0 & 0 & 0 & 0 & 0 \\
\hline & Pisidia longicornis & 66 & 1 & 0 & 2 & 0 & 0 & 0 & 0 & 0 & 3 & 0 & 0 & 97 & 4 \\
\hline & Processa sp. & 0 & 0 & 0 & 0 & 0 & 0 & 0 & 0 & 0 & 0 & 0 & 0 & 1 & 0 \\
\hline & Pseudoparatanais batei & 2 & 0 & 0 & 0 & 0 & 0 & 0 & 0 & 0 & 0 & 0 & 0 & 0 & 0 \\
\hline & Sinelobus stanfordi & 0 & 1 & 0 & 0 & 0 & 0 & 0 & 0 & 0 & 0 & 0 & 0 & 0 & 0 \\
\hline & Socarnes erythrophthalmus & 0 & 0 & 0 & 36 & 0 & 0 & 0 & 0 & 0 & 0 & 0 & 0 & 0 & 0 \\
\hline & Stenothoe marina & 0 & 0 & 0 & 0 & 2 & 1 & 0 & 0 & 0 & 0 & 0 & 0 & 0 & 0 \\
\hline & Tryphosa nana & 1 & 0 & 0 & 0 & 0 & 0 & 0 & 0 & 0 & 166 & 0 & 0 & 2 & 0 \\
\hline & Tryphosella sarsi & 1 & 0 & 0 & 0 & 0 & 0 & 0 & 5 & 0 & 0 & 0 & 0 & 0 & 0 \\
\hline & Unciola crenatipalma & 3 & 0 & 0 & 0 & 0 & 0 & 0 & 0 & 0 & 0 & 0 & 0 & 1 & 0 \\
\hline & Vaunthompsonia cristata & 0 & 0 & 0 & 2 & 11 & 0 & 0 & 0 & 1 & 0 & 0 & 0 & 0 & 0 \\
\hline & Zeuxo holdichi & 0 & 0 & 0 & 1 & 1 & 0 & 0 & 0 & 0 & 0 & 0 & 0 & 0 & 0 \\
\hline & Total number of individuals & 781 & 107 & 18 & 255 & 484 & 39 & 491 & 53 & 64 & 1830 & 53 & 82 & 431 & 60 \\
\hline & Number of taxa & 82 & 29 & 8 & 28 & 33 & 17 & 9 & 16 & 15 & 18 & 21 & 20 & 68 & 19 \\
\hline & $H^{\prime}(\log 2)$ & 5.24 & 3.93 & 2.50 & 2.40 & 2.33 & 3.18 & 0.25 & 3.29 & 2.90 & 2.43 & 3.64 & 3.44 & 4.81 & 3.54 \\
\hline & $\mathrm{J}$ & 0.82 & 0.81 & 0.83 & 0.50 & 0.46 & 0.78 & 0.08 & 0.82 & 0.74 & 0.58 & 0.83 & 0.80 & 0.79 & 0.83 \\
\hline & Volume per station (L) & 30 & 2 & $\leq 0.5$ & 30 & $<1$ & $\leq 0.5$ & $\leq 0.5$ & $\leq 0.5$ & $\leq 0.5$ & 30 & $\leq 0.5$ & $\leq 0.5$ & 15 & $\leq 0.5$ \\
\hline
\end{tabular}

